\title{
Primary and Secondary School Teachers' Perceptions of Workload
}

\author{
Süleyman Göksoy ${ }^{1}$, Şeyma Karaokur Akdağ² \\ ${ }^{1}$ Faculty of Education, Educational Sciences, Educational Administration and Supervision, University of Düzce, \\ Düzce, Turkey \\ ${ }^{2}$ Cemile Çopuroğlu Secondary School, Istanbul, Turkey \\ Email: goksoys@hotmail.com, bjkmhi@hotmail.com
}

Received 13 January 2014; revised 8 February 2014; accepted 28 February 2014

Copyright $@ 2014$ by authors and Scientific Research Publishing Inc.

This work is licensed under the Creative Commons Attribution International License (CC BY). http://creativecommons.org/licenses/by/4.0/

(c) (i) Open Access

\section{Abstract}

The aim of the study is to determine the perception of workload of primary and secondary school teachers in Turkey in accordance with teachers' opinion. The research data were collected using phenomenological pattern which is one of qualitative research methods, and analysis of documents was made. The research was made on 72 Primary and Secondary school teachers who have at least three years seniority working in 24 schools subordinate of Directorate of Istanbul Provincial Education. Data were collected through semi-structured interviews. The analysis of the resulting data was conducted by inductive content analysis. In the study, teachers generally state that security duties of teachers should be transferred to the security companies, and teachers should not interfere to the duty of collecting money from students in no way under any intentions. Again, according to the findings of the research, the most fatiguing, puzzling and time consuming issues as for teachers should be reduced which are, documents and correspondences, student tracking and control, disciplinary procedures, administrative meetings, collection of dues, ceremonies and celebrations, home visits and development of material as well. Questions of survey related to special education and guidance and counseling services should be asked by experts of this section and related ones since the related questions include very special subjects for children; as for data entries, they must be done by the school officers. The results are significant due to the fact that they offer a sight for the stakeholders about the works stated in teachers' job description and the perception of the teachers themselves related to their workload.

\section{Keywords}

Component, Task Definition, Teacher, Workload, Workload Perception 


\section{Introduction}

Traditionally, when the teacher concept is considered a person is thought who is standing in front of the class controlling events, maintaining most of the dialogues, transferring information, asking questions, evaluating, punishing, rewarding, demonstrating, sourcing, definitely the most active and dominant character who is taking all of the responsibilities of the process her/himself. The role of the teaching profession and behavior has changed, especially with the introduction of the concepts such as cooperative learning, active learning, multiple intelligence, life-long learning, creative thinking, constructivist learning into the education system. For instance, according to the constructivist learning approach what the teacher has to do is to mediate between the students and the education program and to facilitate the student's knowledge construction process via preventing the wrong orientation (Açıkgöz, 2003). In cooperative learning, teachers teach students collaborative or social skills, so that they can work together more effectively (Jacobs 1998 by Larsen-Freeman, 2003). What is different from the traditional one is that the active teaching teachers show the direction to the students instead of applying their own decisions, they make recommendations and make a statement when necessary, they give an idea, be a guide and observe student development (Açıkgöz, 2003).

Depending upon change and renewal of the content of job descriptions of teachers, all aspects of preparation, planning, implementation and evaluation, including the teaching-learning process show variation and differentiation. The current stage reached related to teaching duties and responsibilities raises the consequence of an increase in the amount of work that should be done in a unit time without compromising the quality.

\subsection{Problem of Research}

The answers of the following questions were sought:

1) Which tasks are of importance and have priority within the scope of task (job) definition of teachers?

2) Which tasks are the most tiring and time-consuming ones?

3) Which tasks within the scope of job definition of teachers are thought to be out of task definition and should be transferred to a different profession branch?

\subsection{Research Focus}

In this study, it is aimed to determine the perception of workload of primary and secondary school teachers in accordance with teachers' opinion.

Workload can be expressed as the amount of work that should be done at a certain time with a certain quality (Maslach, 1999, by Sağlamarı \& Çınabal, 2008). As for workload perception, it is relative which may vary in accordance with the circumstances that the teacher has been experiencing. The concept workload is the perception that the work loaded above normal to the individual in the workplace. For most of the job, if the natural load of the work has not been calculated mathematically, it is possible to state that this concept has an abstract content based on the perception (Keser, 2006).

Since the workload is a common cause for teachers to leave the profession (DCSF, 2010), a lot of researches on this subject were made in the world especially in Europe in recent years; namely, in a study on teachers in Scotland, $80 \%$ of primary school teachers, and $90 \%$ of secondary school teachers stated that implementation of job sizing had adversely affected their workloads and had resulted in an unsatisfactory outcome for teachers in their own schools (NASUWT, 2006). In a survey related to workload pressure in 2010 by New Zealand Post Primary Teachers' Association, nearly 50\% of teachers reported an increase of workload arising from the National Standards (New Zealand Post Primary Teachers’ Association, 2010).

The 2010 Teachers' Workload Diary Survey provides independently collected data on hours and working patterns in maintained schools in England and Wales. The survey also takes into account teachers' perception of their workload. Less than a fifth of teachers who answered reported that they were expected to do things that were not part of their job all/most of the time. Slightly more thought they were unable to do things that should be part of their job all/most of the time. Less than a quarter of full time teachers felt their workload allowed them to pursue personal interests outside work all/most of the time. In the 2010 survey, average hours worked per week remain above 50 hours for most types of teacher, with only secondary school and special school classroom teachers working, on average, slightly less than 50 hours per week (DCSF, 2010).

Duties and responsibilities containing the workload of teachers in Turkey are determined by legislation. 
Namely, in National Education Basic Law No 1739, Teaching is a special expertise profession which undertakes education, training and related management tasks of the state. Teachers are obliged to perform these tasks, in accordance with the objectives and basic principles of Turkish National Education (Retrieved 07/12/2012 from http://mevzuat.meb.gov.tr). There exists the mention "teachers can not be obliged with any tasks out of profession but only obliged with the tasks they are given by laws.” in the article 44 of Primary Fundamental Law No. 222 which has been published in 1961 and still in force (Retrieved 08/02/2012 from http://mevzuat.meb.gov.tr)

In Turkey, the related tasks of teachers working in elementary and secondary schools were expressed in detail in the Ministry of Education Primary Foundations Regulation (Amended: RG-21/7/2012-28360 and in the Ministry of Education Regulations of Social Activities For Fundamental and Senior Training Foundations (RG No. 13.1.2005/25699). For instance, some of the works that classroom teachers need to do in accordance with the Ministry of Education Primary Foundations Regulation are as follows: new registrations of students (Article 17), student development files (Article 23), tracking of attendance (Article 27), measurement \& assessment (Article 33 - 44), transcripts (Article 41), student behaviors (Article 43 - 48), class upgrade (Article 49), training courses (Article 50), perusing written orders (Article 65), the additional tasks given (Article 68), participation to the meetings (Article 69), use of tools and equipment (Article 70), teachers' guard duty (Article 71), boards, vocational studies and commissions (the teachers board, teachers group of same branches, teachers group of same classes) (Article 94 - 96), students board and school counsil (Article 97), vocational studies (Article 98), the school development management team (Article 99), purchasing commission (Article 100), inspection and acceptance commission (Article 101) (Amended: RG-21/7/2012-28360 (Retrieved 02/08/2012 from http://mevzuat.meb.gov.tr).

The sub areas that the workload affect individuals negatively consists of uncertain task undertake, the pressure related to the time that the individual is obliged to do the work, incompatible and inappropriate training and development and the low level of social support (UEW, 2005, by Keser, 2006). In this sense, the opinions of teachers related to their work load are necessary and important in terms of the analysis and improvement of the work done. For that reason, the aim of the study is to determine the perception of workload of primary and secondary school teachers in accordance with teachers' opinion.

\section{Methodology of Research}

\subsection{General Background of Research}

The research data were collected using phenomenological pattern which is one of qualitative research methods. Therefore, in order to understand the individual perspectives and behaviors of the teachers reflected in the social world, it is aimed to resolve structures and the relationships they use in everyday life and to expose the hidden meanings.

The descriptive statistics analysis method was used to analyze the data. Inductive analysis which is one of the content analysis types was used to resolve the obtained under in scope of the study. Inductive analysis is performed in order to reveal the concept underlying the data and the relationship between those concepts via encoding (Yıldırım \& Şimsek, 2005).

\subsection{Instrument and Procedures}

The data were collected via a semi-structured interview form in the study. During the process of preparation of the interview form, a detailed literature review was carried out and important concepts related to workload and perception of workload were identified. As a result of this process, a semi-structured interview was obtained consisting of three open-ended questions. The interview was submitted to the opinion of teachers (five teachers) still serving and faculty members working in the field of science of education (three academics) before the application and the content and face validity was tested.

\subsection{Sample of Research}

The research was made on 72 primary and secondary school teachers who have at least 3 years seniority working in 24 schools subordinate of Directorate of İstanbul Provincial Education in 2011-2012 academic year. Teachers and their schools were determined by maximum variation sampling. Maximum variation sampling is to create a relatively small sample and to reflect the diversity of individuals that might be a party of the problem 
studied on that sample (Yıldırım \& Şimşek, 2005). The reason for requirement of being staff and having at least 3 years of experience is the endeavour of an accurate data collection in terms of perception of workload of teachers. Thus, three teachers from each school were interviewed during an average of 20 minutes.

To ensure a voluntary participation, the teachers who are voluntary are requested to answer the questions and the data were collected. Information related to participants is presented in Table 1.

When the data are analyzed in Table 1, it is seen that women in the research constitute the majority of teachers. While the majority of teachers are at undergraduate degree, the proportion of graduate (license) degree is at the level of 22 percent. As for experience, 38 percent of teachers have 3 - 5 years, 17 percent of them have between 6 - 10 years, while 26 percent have 11 - 15 years of teaching experience, and over 25 years of experience has the least percentage with $3 \%$ and the teachers have been continuing their services.

\section{Data Analysis}

The data were analyzed in four stages: data coding, identification of themes of the data encoded, regulation of the codes and themes, and the identification and interpretation of the findings (Yıldırım and Şimşek, 2005). Accordingly, the data were arranged and encoded, creation of the themes from the encoded was done and in that direction the repetition frequency of the findings were identified and interpreted by expressing via frequencies and percentages. Analyzed forms were given sequence numbers and shown in parentheses at the end of the direct quotations, and care has been taken to conceal the names of participants who are considered to give personal information. The data compatible with the conceptual framework were described as findings. The common concepts and themes achieved were presented as research findings at the end of the analysis conducted independently by two researchers.

\subsection{Validity and Reliability}

Concepts such as validity and reliability are found as dogmatic and criticized as a product of the deductive approach of the positivist paradigm based on hypothesis testing, within the tradition of qualitative research. Instead of that, it is seen that concepts such as credibility and transferability are more preferred (Yıldırım \& Şimşek, 2008). In this direction, in order to increase the credibility of research to reveal the transferable properties for similar environments, the interview forms were analyzed by two separate researchers, and it was described the way the results were accessed and critical and comparative analysis were included during the interpretation of data and presented with direct quotation.

\subsection{Results of Research}

This section is consisted of views of teachers in the context of the themes and emerging concepts. In this direction, teacher views related to the workload specified as the amount of the work to be done at a certain time and a certain quality and the work load perceptions of the teachers' which may vary according to the circumstances of

\begin{tabular}{cccc}
\multicolumn{3}{l}{ Table 1. Personal information related to teachers. } \\
\hline Variables & Sub Categories & $n$ & $\%$ \\
\hline \multirow{2}{*}{ Gender } & Female & 43 & 60 \\
& Male & 29 & 40 \\
& Associate & 1 & 1.39 \\
Education & Undergraduate & 55 & 76.39 \\
& Master & 16 & 22.22 \\
& PhD & 0 & 0 \\
Year of Teaching & 3 - 5 years & 27 & 37.5 \\
Service & 6 - 10 years & 12 & 16.67 \\
& 11 - 15 years & 19 & 26.39 \\
& 16 - 20 years & 12 & 16.67 \\
& 25 and above & 2 & 2.77 \\
\hline
\end{tabular}


teachers are presented under the headings, and in the background, it is targeted to determine their workload perceptions.

1) Works that are of importance and priority within the scope of task definition of teachers

Alignment of tasks stated in legislation, according to importance and priority in accordance with teachers' perceptions is examined under this heading. Therefore teachers' statements of their own perspectives are important in terms of reflecting a sincere view related to the sequence of works in accordance with importance and priority. The tasks in teachers' task definition that are considered as important and prior by teachers are presented in Table 2.

When the emerging themes are examined in Table 2, it can be seen that the tasks in teachers' task definition that are considered as important and prior by elementary and secondary school teachers are teaching, learning activities $(n=70)$, student counseling services $(n=43)$, paperwork/data entry and correspondence $(n=37)$, meetings ( $(n=14)$, guard duty $(n=12)$, planning $(n=11)$, measurement and assessment works $(n=8)$, disciplinary works $(n=7)$, professional development $(n=7)$, social activities $(n=6)$, ceremonies and celebrations $(n=$ 6), parents' meetings $(n=6)$, boards and commissions $(n=5)$, communication with colleagues $(n=4)$, R \& D and projects $(n=4)$, material development $(n=4)$, educational trips $(n=3)$, tracking of absenteeism $(n=3)$, and collection of dues $(n=2)$ respectively.

Available data demonstrates that teachers align the works they have been doing from more important to less important ones and from more prior to less prior ones in accordance with their views. Namely as for importance and priority according to teachers, top five is highlighted as teaching and learning activities, student counseling services, data entry and correspondence, meetings and the last five as the least important and prior is the R \& D and projects, material development, educational trips, attendance (absenteeism) tracking and collecting dues.

"Some of the direct quotations including to teachers views related to the important and prior teacher tasks are as follows:"

"Planning the works and processes that should be done in the school, and distribution of the tasks, preparation for lessons and the course presentation ( $T$ 1)", Making studies in order to improve the quality of education and training, to enter the lessons in time (T 4)", "individual educational, vocational, protective and preventive,

\begin{tabular}{lcc} 
Table 2. Works that are of importance and priority in accor- \\
dance with the teachers' views. & \multicolumn{3}{l}{} \\
\hline Themes & 70 & 97 \\
\hline Teaching-learning activities & 43 & 60 \\
Student Counseling Services & 37 & 51 \\
Paperwork/data entry and correspondence & 14 & 19 \\
Meetings & 12 & 17 \\
Guard Duty & 11 & 15 \\
Planning & 8 & 11 \\
Measurement-Assessment Works & 7 & 10 \\
Disciplinary works & 7 & 10 \\
Professional Development & 6 & 8 \\
Social Activities & 6 & 8 \\
Ceremonies and Celebrations & 6 & 8 \\
Parents' meetings & 5 & 7 \\
Board and Commissions & 4 & 6 \\
Communication with colleagues & 4 & 6 \\
Research \& Development and Projects & 4 & 6 \\
Material development & 3 & 4 \\
Educational trips & 3 & 4 \\
Tracking of absenteeism & 2 & 3 \\
Collecting dues & &
\end{tabular}


descriptive counseling services, individual acquaintance techniques, works related Counseling and Research Centers and the IEP (Individualized Education Planning process (T 19)", "Allowing time for material development (T 20)", "Development of national and international projects ( $T$ 23)", "supporting the readiness and capabilities, motivating students, raising the student achievement, preparing students to life (T 38)", "Giving the gains appropriate for course content (T 42)", "Dealing with student behavior, ensuring the classroom discipline, making the students adapt to the school rules, doing documentary works and formal procedures (T 49)", "guard duty (T 51)", "improve myself about the field knowledge and skills following innovation and developments regarding the field, attending seminars ( $T$ 53)", "Conducting the meetings of teachers of same branch, participating in administrative meetings ( $T$ 58)", "organizing travels and trips to theaters, museums and so on (T 59)", "Doing extracurricular activities ( $T$ 60)", "preparation for feast ceremonies and certain days and weeks, doing the celebration programmes (T 33)", "entering data to e-school module (T 7)", "Preparation and evaluation of performance tasks and project assignments, preparation of, portfolios and product files, test exam applications (T 61)”

2) Sequence of priority of the most fatiguing and time consuming tasks that are in task definition of teachers

Teachers' perceptions regarding the most fatiguing, puzzling and time consuming tasks being in task definition of them in their point of views are presented in sequence of priority in Table 3.

In Table 3, when the emerging themes are examined, the most fatiguing, puzzling and time consuming works for primary and secondary school teachers are indicated as data entry, paperwork and correspondence $(n=42)$, student counseling services $(n=27)$, measurement and assessment $(n=17)$, guard duty $(n=16)$, control and tracking of students $(n=15)$, disciplinary works $(n=8)$, administrative meetings $(n=6)$, due collection $(n=6)$, ceremonies and celebrations $(n=5)$, home visits $(n=4)$, material development $(n=3)$, communication with colleagues ( $(n=3)$, social activities $(n=3)$, and competition $(n=2)$ respectively.

According to the available data, top five of the most fatiguing, puzzling and time consuming works for teachers is stated as data entry, paperwork and correspondence, student counseling services, measurement \& assessment and guard duties while the least fatiguing, puzzling and time consuming works are highlighted as material development, communication with colleagues, social activities and competitions.

Direct quotations including the teachers views related to "the most fatiguing and time consuming works" are as follows:

"Regulations regarding the physical structure and usage (T 7)", "tracking the works related to education and instruction (T 10)", "doing data entry to e-school-filling the computer with unnecessary data (T 13)", "Guard duty (T 27)", "preparing reading and evaluating the essays, project-performance tasks, scales and rubrics, filling out the, observation forms and evaluation forms, to, preparation of the portfolios, preparing worksheets (T 28)", "Preparing the material ( $T$ 30)", "tracking the absenteeism, ensuring the attendance ( $T$ 35)", "paperwork,

Table 3. The most fatiguing and time-taking works for teachers.

\begin{tabular}{lll}
\hline Themes & $n$ & $\%$ \\
\hline Data entry, paperwork and correspondence & 42 & 58 \\
Guidance for Students & 27 & 38 \\
Measurement-Assessment & 17 & 24 \\
Guard Duty & 16 & 22 \\
Control and Tracking of Students & 15 & 21 \\
Disciplinary Works & 8 & 11 \\
Administrative Meetings & 6 & 8 \\
Due Collection & 6 & 8 \\
Ceremonies and Celebrations & 5 & 7 \\
Home Visits & 4 & 6 \\
Material Development & 3 & 4 \\
Communication with colleagues & 3 & 4 \\
Social Activities & 3 & 4 \\
Competitions & 2 & 3 \\
\hline
\end{tabular}


preparing files, filling out and interpreting the forms and questionnaires ( $T$ 39)", “communication among teachers (T 42)", "Caring about student behavior, disciplinary problems and behavioral disorders, making the students gain the desired behaviour ( $T$ 45)", “collecting money to spend for classroom and students ( $T$ 48)”, "making preparations for the celebrations of feasts and certain days and weeks, preparation for literacy feast for the first grade students (T 50)”, "Doing Extra-curricular activities (T 54)”, “Making parent interviews, home visits (T 55)”, “Holding and participating the meetings (T 60)”, “Doing administrative Works and processes, attending to the seminar studies (T 62)".

3) Tasks within the scope of task definition of teachers but thought to be out of task definition and should be transferred to a different profession branch

The teachers' perceptions related to the tasks within the scope of task definition of teachers but thought to be out of task definition and should be transferred to a different profession branch are presented in Table 4.

When the emerging themes are examined in Table 4, tasks within the scope of task definition of teachers but thought to be out of task definition and should be transferred to a different profession branch are highlighted as collection of dues and donation $(n=21)$, Out of school guidance (parental, environmental) $(n=20)$, documentation and filing $(n=19)$, distinctive education services $(n=14)$, guard and security works $(n=10)$, e-school data inputs $(n=9)$, arrangement of physical structure, and cleaning $(n=8)$, such a task does not exist $(n=7)$, administrative tasks and meetings $(n=5)$, control of health and self-care $(n=5)$, and social clubs $(n=5)$.

"The direct quotations related to teacher views of the tasks within the scope of task definition of teachers but thought to be out of task definition and should be transferred to a different profession branch" are as follows:

"Developmental tracking of individuals who require special training must be made by counseling services and special educators (T 2)", "guard duty should be transferred to security companies, municipalities or servants, it should not be my mission to ensure the security of the students in school or classroom (T 9)", "Donation, social assistance, collection and distribution of cleaning fee should be transferred to PTA (school and family association) (T 12)", "e-school data entry, form filling, and various surveys should be done by the officers ( $T$ 21)", “attendance tracking, interviews of parents in due time of registration (T 22)”, "paperwork is unnecessary must be made by the officers, and filling out the questionnaires is not in scope of my task definition, filling out the class book should not be my task (T 25)", “Distribution of milk or tracking the students' eating habits (T 43)", "to provide the physical facilities of the class or to carry the desks into the classroom of a newly established school (T 55)”, "to prepare base materials for education-training ( $T$ 59)", "to make students' health checks, giving health services, to care about students who have not attained potty training, cleaning control should not be transported to schools, there should be health officials in schools (T 60)", "I think that extracurricular activities or taking part in kermes or entertainment organizations are not my task as a teacher, (T 29)”, "A new staff employment should be done for education of family members, and parents, new staff should be trained accordingly, the number of counselor-teachers should be increased, all of the unfavourable events (the cases with mental and behavioral problems) are not my task (T 32)”, “actuating school marching band (T 34)”,

\begin{tabular}{|c|c|c|}
\hline Themes & $n$ & $\%$ \\
\hline Collection of dues and donation & 21 & 29 \\
\hline Out of school guidance (parental \& environmental) & 20 & 28 \\
\hline Documentation and Filing & 19 & 26 \\
\hline Distinctive Education Services & 14 & 19 \\
\hline Guard-Security Works & 10 & 14 \\
\hline e-school data input & 9 & 13 \\
\hline Arrangement of Physical Structure & 8 & 11 \\
\hline Such a task does not exist & 7 & 10 \\
\hline Administrative tasks and meetings & 5 & 7 \\
\hline Control of Health and Self-Care & 5 & 7 \\
\hline Social clubs & 5 & 7 \\
\hline
\end{tabular}


"Works that should be done by administrative staff should not be transferred to us (T 37)", "Counseling to social clubs should not be my mission, professional groups or specialist teachers should be employed for the courses related to social activities (T 39)", "parents to be informed (T 40)", "I think examinations are excessive (T 41)".

\section{Discussion}

The findings of this research supports the findings of NASUWT (New Zealand Post Primary Teachers' Association, 2010) as for increase of workload stated by teachers. The results of the research also supports the findings of DCSF in England and Wales the 2010 Teachers' Workload Diary Survey which also takes into account teachers' perception of their workload reporting that the teachers were expected to do things that were not part of their job all/most of the time (DCSF, 2010). Further qualitative and quantitative researches could be done for perception of workload by educators.

\section{Conclusions and Recommendations}

The opinions of teachers related to their work load are necessary and important in terms of the analysis and improvement of the work done. For that reason, the aim of the study is to determine the perception of workload of primary and secondary school teachers in accordance with teachers' opinion. It is derived from the research that the tasks considered as of importance and priority are highlighted by primary and secondary school teachers as teaching, learning activities, student counseling service, data input and correspondence, meetings, guard duty, planning, measurement and assessment works, disciplinary works, professional development, social activities, ceremonies and celebrations, parents' meetings, boards and commissions, communication with colleagues, Research and Development (R \& D) and projects, material development, educational trips, non-attendance (absenteeism) tracking, and collecting dues, respectively.

Available data demonstrate that teachers align the works they have been doing from more important to less important ones and from more prior to less prior ones in accordance with their views. Namely as for importance and priority according to teachers, top five is highlighted as teaching and learning activities, student counseling services, data entry and correspondence, meetings and the last five as the least important and prior is the R \& D and projects, material development, educational trips, attendance (absenteeism) tracking and collecting dues.

The most fatiguing, puzzling and time consuming works for primary and secondary school teachers are stated as data entry, paperwork and correspondence, student counseling services, measurement and assessment, guard duty, control and tracking of students, disciplinary works, administrative meetings, due collection, ceremonies and celebrations, home visits, material development, communication with colleagues, social activities, and competition respectively.

Tasks within the scope of task definition of teachers but thought to be out of task definition and should be transferred to a different profession branch are highlighted as collection of dues and donation, out of school guidance (parental, environmental), documentation and filing, distinctive education services, guard and security works, e-school data inputs, arrangement of physical structure, and cleaning, such a task does not exist, administrative tasks and meetings, control of health and self-care, and social clubs.

Following recommendations can be made in accordance with the discussion and interpretation of obtained findings of the research: Guard duties should be transferred to the security companies. Teachers should not interfere to the duty of collecting money from students in no way in terms of their image from students' sight. Paperwork and correspondence, control and tracking of students, disciplinary works administrative meetings, due collection, home visits, material development which are the most fatiguing, puzzling and time consuming works for teachers should be reduced. Since the surveys related to distinctive education and counseling services include very confidential questions related to children, the questions in the surveys should be asked by related counselors and specialists and data entries must be made by the officers.

\section{Acknowledgements}

The authors hereby give their acknowledgements to the elementary and secondary teachers who replied the survey used in this study and have been working in schools of Directorate of Ministry of Education in Pendik district of İstanbul. 


\section{References}

Açıkgöz, Ü. K. (2003). Aktiföğrenme (Active Learning) (pp. 34, 38, 65). İzmir: EğitimDünyası Press.

Keser, A. (2006). ÇağrıMerkeziÇalışanlarındaİşYüküDüzeyi İle İşDoyumüllişkisininAraştırılması (Research of Workload Level and Job Satisfaction of the Call Center Personel). Kocaeli Üniversitesi Sosyal Bilimler Enstitüsü Dergisi (Journal of Kocaeli University Institute of Social Education), 1, 100-119.

Larsen-Freeman, D. (2003). Techniques and Principles in Language Teaching (2nd ed., p. 164). Oxford: Oxford University Press.

Milli Eğitim Bakanlığı (Ministry of National Education) (2012). ÖzelKalem Müdürlüğü Executive Assistance Directorate 2012/20 Sayılı "12 Y1llı Zorunlu Eğitime Yönelik Uygulamalar” Genelgesi (Circular Regarding the Implementation of 12 Year Compulsory Education). http://www.meb.gov.tr/mevzuat/liste.asp?ara=9\&Submit=Listele

Milli Eğitim Bakanlığı İlköğretim 1-5. Sınıf Programları Tanıtım El Kitabı. (Ministry of National Education Fundamental Education 1-5 Classroom Grade Programmes Introduction Manual (2005). Ankara: MEB TTKB (Ministry of National Education Board of Education).

NASUWT (National Association of Schoolmasters Union of Women Teachers) (2006). Teachers’ Workload and Working Hours.

http://www.nasuwt.org.uk/consum/groups/public/@salariespensionsconditions/documents/nas_download/nasuwt_000360. pdf

New Zealand Post Primary Teachers’ Association, Wellington (2010). PPTA Members and National Standards Report on Assessment Workload Survey. http://www.ppta.org.nz/index.php/resources/publications/doc_download/1086-ppta-members-and-national-standards-repor t-on-assessment-workload-survey

Sağlamarı, G., \& Çınabal, B. (2008). Tükenmislik Kavramı: Bireyve Örgütler Açısından Önemi (Burnout Concept: Its Importance in Terms Of Individual and Organisations). YönetimveEkonomi Cilt:15, Sayı:1 Celal Bayar Üniversitesi, İ.İ.B.F Manisa,2008, s.131)(Management and Economy Volume:15, Number:1 Celal Bayar University, Economics and Administrative Sciences Manisa, 2008, p. 131)

www2.bayar.edu.tr/yonetimekonomi/dergi/pdf/C15S12008/131_148.pdf

The Department for Children, Schools and Families (DCSF) (2010). Teachers’ Workload Diary Survey. www.education.gov.uk/publications/eOrderingDownload/DFE-RR057-WEB.pdf

Yıldırım, A., \& Şimşek, H. (2005). Sosyalbilimlerdenitelaraştırmayöntemleri (Qualitative Research Methods in Social Sciences) (5th ed.). Ankara: Seçkin. 
Scientific Research Publishing (SCIRP) is one of the largest Open Access journal publishers. It is currently publishing more than 200 open access, online, peer-reviewed journals covering a wide range of academic disciplines. SCIRP serves the worldwide academic communities and contributes to the progress and application of science with its publication.

Other selected journals from SCIRP are listed as below. Submit your manuscript to us via either submit@scirp.org or Online Submission Portal.
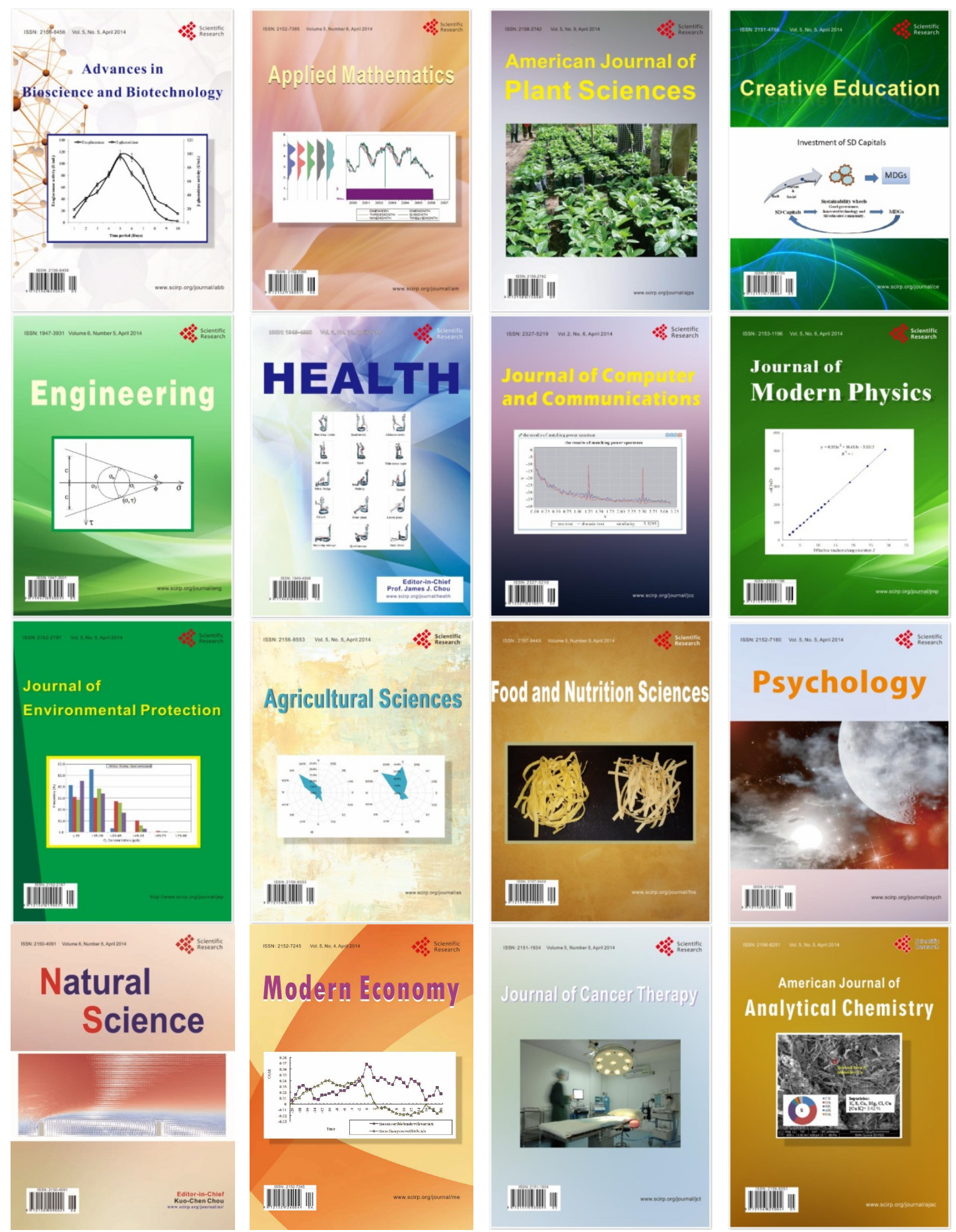